\title{
ЮРИДИЧНІ НАУКИ
}

\author{
УДК 342.537.3(477.83):340.131 - 05;342.15(477)
}

DOI: $10.15587 / 2313-8416.2015 .36172$

\section{ЗАКОНОПРОЕКТИ Ю. РОМАНЧУКА ЯК ПРАВОВА ОСНОВА ДЕМОКРАТИЧНОГО РОЗВИТКУ ГАЛИЦЬКОГО СУСПІЛЬСТВА}

\section{А. І. Мельник}

\begin{abstract}
Досліджується законотворча діяльність Ю. Романчука як голови “Народної Ради”, лідера Украӥнської національно-демократичної партії, очільника украӥнських парламентських представництв у Галицькому крайовому сеймі (1883-1897 рр.) та Державній Раді у Відні (1891-1897 і 1901-1918 рр.). Узагальнюється його внесок в розробку законопроектів, які сприяли демократизації галицького суспільства та послужили правовою основою для офіиіийного визнання в Австро-Угорській монархії украӥнського національного руху та легітимності процесу відновлення украӥнської державності
\end{abstract}

Ключові слова: конституціийні закони, національні парламентські представництва, національнотериторіальна автономія, виборча реформа

It is analyzed the legislative activity of Y. Romanchuk as a Chairman of People's Council, the leader of Ukrainian National Democratic Party, the leader of Ukrainian parliamentary representation in Galician Sejm (1883-1897) and State Council in Vienna (1891-1897 and 1901-1918). It is summarized his contribution in the development of draft lows, that have contributed to democratization of Galician society and served as the legal basis for the official recognition of the Ukrainian national movement and legitimacy of the recovery process of Ukrainian statehood in Austro-Hungarian monarchy

Keywords: constitutional laws, national parliamentary representations, national and territorial autonomy, electoral reform

\section{1. Вступ}

У наш час помітно посилився інтерес до об'єктивного дослідження українського відродження в другій половині XIX - на початку XX ст., і зокрема, до проблематики становлення та розвитку вітчизняного парламентаризму та участі його представників в роботі законодавчих органів Австро-Угорщини. Серед низки історичних постатей цього періоду особливо важливе місце посідає Юліан Романчук - талановитий український політик і державний діяч, який понад тридцять років життя присвятив законотворчій діяльності. Саме під керівництвом Ю. Романчука як голови "Народної Ради", лідера Української національно-демократичної партії, очільника українських парламентських представництв у Галицькому крайовому сеймі (1883 - 1897 рр.) та Державній Раді у Відні (1891-1897 і 1901-1918рp.), західноукраїнське суспільство перейшло до сміливої, повсякденної боротьби за офіційне визнання в Австро-Угорській монархії українського національного руху та проголошення в Галичині незалежної Української держави.

\section{2. Постановка проблеми}

Метою цієї публікації $\epsilon$ аналіз діяльності Ю. Романчука в парламенті Австро-Угорщини, дослідження його впливу на розробку та прийняття законопроектів, які послужили правовою основою для демократичного розвитку галицького суспільства та легітимності процесу відновлення української державності.
Актуальність досліджуваної проблематики пояснюється не лише академічною необхідністю всебічного й об'єктивного дослідження українського відродження в другій половині XIX - на початку XX ст., a й науково-практичним значенням інтелектуальної спадщини Ю. Романчука, в якій відображені чіткі орієнтири і напрями еволюційних шляхів розбудови правової держави та розвитку громадянського суспільства, формування правового механізму функціонування державної влади, утвердження прав і свобод людини.

\section{3. Літературний огляд}

Тема цієї статті не була раніше безпосереднім об'єктом вивчення історико-правової науки. Певні напрямки парламентської діяльності Ю. Романчука проаналізовано в контексті дослідження політики “нової ери”, форм і методів депутатської практики українських парламентарів у працях О. Аркуші, В. Булачека, В. Качкана, М. Мудрого, О. Пилипишина, I. Чорновола та ін. Тоді як питання права є малодослідженими.

Для аналізу правових поглядів Ю. Романчука автор використав публікації в тогочасних періодичних виданнях, зокрема, в газеті “Діло”, де була опублікована промова Ю. Романчука на Других загальних зборах Народної Ради 26 грудня 1890 р [1], а також стенографічні звіти про діяльність українських парламентарів у Галицькому крайовому сеймі та Державній Раді у Відні - Stenograficzne sprawozdania Sejmu 
krajowego Krolestwa Galicyi I Lodomeryi wraz $\mathrm{z}$ wielkiem Księstwem Krakowskiem z roku 1895/96 od 28 grunia 1895 do 8 lutego 1896 [2] i Republik Österreich. Parlamentsdirektion (Abt. Parl.Dok./Archiv) 508. Sitzsung der XI. Session am 6. Juni 1896. S. 25832 [3].

\section{4. Законопроекти Ю. Романчука як легіти-} мне підгрунтя в процесі самоорганізації та політичного самовизначення українського населення Галичини

Боротьбу за інтереси українського населення Галичини Ю. Романчук вів на платформі оновлення Австро-Угорщини, шляхом реформування держави на основі встановленого конституційного ладу, який формально визнавав “правила гри” суб'єктів міжетнічної взаємодії й надавав можливості для легітимного захисту ними своїх групових інтересів тощо [4]. Згідно з Конституцією 1867 року поляки і руські (тобто українці - А. М.), а також інші народності, що проживали в коронному краї, були рівними в управлінні, і кожен народ мав непорушне право до збереження і розвитку своєї народності і своєї мови [5]. Однак у різних краях Австро-Угорщини закони трактувались по-різному, залежно від впливу тих чи інших політичних сил. У Галичині, де в руках у поляків були всі місцеві адміністрації, судочинство, засоби зв'язку, їх представники саботували будь-яку пропозицію, спрямовану на поліпшення становища українців.

Поліпшити ситуацію Ю. Романчук прагнув шляхом внесення змін до конституційних законів. Виступаючи 26 грудня 1890 р. на других загальних зборах "Народної Ради”, він заявив, “щоби теперішне так тяжке і прикре положення русинів поправилося, мусять наступити зміни:

a) в виконуванні заповітів і постанов і взагалі в цілім поступуванні правительства і його органів,

б) в некорисних для для русинів постановах $\mathrm{i}$ розпорядженнях, усуненням їх і заступленням новими в дорозі адміністраційній,

в) в некорисних для русинів законах, знесенням їх і заступленням новими в дорозі законодавчій" [1].

Будучи твердо переконаним, що “потрібна взагалі зміна цілої системи правительственної, цілого поступування правительства супроти русинів в тім напрямі, щоби русини і руські справи та інтереси були зовсім з рівною прихильностею трактовані, як кожді інші" [1], Ю. Романчук вимагав від властей:

1) щоби при обсаджуванні вищих посад в адміністрації, судівництві увзгляднено також русинів;

2) щоби руські урядники і учителі против своєї волі не були переношені в західну Галичину, а ті, що суть вже в західній Галичині, щоби могли звідтам вернути до східної;

3) щоби урядники і учителі русини при авансах і в кождім взгляді були нарівні трактовані з другими;

4) щоби в міністерстві просвіти був один вищий урядник русин для справ руського шкільництва i греко-католицької церкви;
5) щоби для руських шкіл народних інспекторами окружними і учителями іменовано тільки такі особи, котрі докладно знають руський язик;

6) щоби при обсаджуванні греко-католицьких капітул і парохій уважано передовсім на спосібність і заслуги компетентів;

7) щоби при виборах до всяких тіл репрезентаційних правительственні власті і органи заховувалися зовсім безсторонно і тілько строго пильнували законного порядку, а при виборах до рад громадських i повітових уможливляли при тім ще вибір людей спосібних і вповні відповідних;

8) щоби руські товариства, інституції, корпорації, згромадження, як і поодинокі особи під кожним виглядом були нарівні трактовані з другими [1].

Звісно, Ю. Романчук усвідомлював, що уконституювати українську державність в Галичині одномоментно не можна. Тому прагнув “щоби той поступ відбувався постепенно, а не наглими і великими скоками" [2]. Лідер народовців уважав за потрібне так змінити конституційні та нормативні акти, “щоби у східній Галичині були постановлювані лише такі урядники і судії, котрі викажуться докладним знанням руського язика в слові і письмі, а всі цивільні власті, уряди і суди в східній Галичині супротив руських сторін, навіть без ініціативи тих же, в слові і письмі уживали тілько руського язика, а до руського письма тілько руських букв“ [1]. Домагався він також, щоб на всіх адміністративних будинках краю написи були зроблені українською мовою. Для цього в Ю. Романчука були правові підстави, адже цісарські постанови від 20 жовтня 1852 р. та від 10 квітня 1861 р., а також розпорядження міністерства внутрішніх справ від 22 жовтня 1852 р., міністерства справедливості від 24 березня, 8 жовтня, 9 липня, 7 серпня і 28 жовтня 1860 р., 21 квітня і 24 листопада 1861 р., 5 червня і 11 серпня 1869 р., унормували вищезгадані питання.

Ці життєво важливі проблеми Ю. Романчук прагнув розв'язати 3 допомогою відміни виборчих курій, запровадження прямих виборів, таємного голосування і внесення відповідних змін до загальнодержавної виборчої системи. Однак “польське сторонництво” (консерватори), по-перше, “поступовало против Русинів з цілою завзятостею”, стараючись без огляду на приналежність до партії та особистість не допустити їх до сейму; по-друге, урядові органи допускалися разючих зловживань, які суперечать не лише духу конституції, але навіть “здоровій політиці”; i, по-третє, польська сеймова більшість діє при затвердженні посольських мандатів “зовсім самовільно" [6].

Наочним прикладом свавілля місцевих властей була заборона в краї народних віче. Користуючись статусом посла, Ю. Романчук подав термінове внесення до парламенту, в якому наголосив, що мова йде “про справу важну, наглячу і доконечну...” [7], бо “вона дотикає горожаньских прав тяжко гнобленого i ві многім упослідженого народу; відтак відносить ся она до принципу свободи і панованя закона над самоволею та сваволею, а тим самим се справа вже не одного народу, лиш всіх народів разом" [7]. 
Термінове внесення Ю. Романчука підтримала газета “Діло”, яка розцінила заборону публічних зборів як грубе порушення міністерством внутрішніх справ конституційних норм держави [8]. Адже Закон про об'єднання й збори (від 15 грудня 1867 р.) давав громадянам певні можливості для забезпечення як прав людини, так і прав окремих народів, які могли бути скасовані лише за виняткових обставин. Однак у Галичині не було "стану виїмкового“, а все таки влада заборонила проведення масових зібрань у краї. Причини заборони, наведені властями, “були цілком маловажні і служили очевидно лише покривкою...” чи то “епідемічна недуга в якій сусідній місцевости” або “в деяких місцевостях повіта", чи то “взгляд на публічний спокій” чи то будівничо-поліційні взгляди (“бо стодола призначена на віче, єсть за мала і могла би погоріти!”) і т. п. [7].

На думку Ю. Романчука, така поведінка, була “цілком самовільною і протизаконною конфіскатою одного 3 найважнійших прав горожаньских” [7]. Для прийняття подібних заходів, зазначав він, не було вагомих підстав. Свавілля властей різко дисонувало зі задекларованими в законах (1849 і 1873 рр.) намірами держави підвищити інструментальний рівень політичної участі громадян шляхом їх залучення до процесу ухвалення рішень і запобігання розв'язання конфліктів через двосторонню взаємодію громадських організацій та органів місцевого самоврядування [9].

Та все ж, попри свою недосконалість, як зазначає I. C. Монолатій, принцип національної рівноправності відкривав усім народам держави засадничо рівний шлях до здобутків тогочасної демократії, стимулюючи, а подекуди - просто змушуючи слабших до прискореного розвитку, аби зрівнятись із політично сильнішими [10]. Тому Ю. Романчук докладав повсякденних зусиль для зростання політичного впливу українців у законодавчому органі імперії: ініціював створення законопроектів для гармонізації національних відносин в Галичині. 3 плином часу прийняті в австрійському парламенті нормативні документи стали легітимним підгрунтям у процесі самоорганізації та політичного самовизначення українського населення краю.

Місія законодавчої влади Австро-Угорщини, вважав Ю. Романчук, має полягати в тому, щоби найчисельніші народи, що проживали між Німеччиною і Росією, (зокрема, українці - А. М.) знайшли тут безпеку свого національного існування й захист своїх культурних і економічних інтересів. Насправді ж парламент у багатьох випадках був просто “машиною обробки законів", більшість з яких не обговорювалися і не приймалися належним чином [3]. Саме тому "одна 3 двох рівно численних народностей краю, тобто руська, наголошував Ю.Романчук, придавлена до крайньої безсильности. Русинів все і всюди майоризують, і не допускають до найважнійших конституційних прав" [11].

Щоб покласти край цій несправедливості, очільник українського парламентського представництва наполегливо добивались прийняття закону про національну автономію з проведенням виборчої реформи. Йшлося, власне, про зміну дотеперішньої австрійсь- кої конституції, яка вже багато років насправді ефективно не функціонувала, й держава опинилася в стані цілковитого розладу.

"У справі виборчій, - наголошувалось в одному із внесень Ю. Романчука, - треба би поступити дальше, коли хочемо станути на твердій і непохитній підставі. - Добре рішення виборчої реформи причинило би ся також багато і до щасливої розв'язки національних спорів” [12].

Уже в наступному році була оприлюднена позиція українських послів про підтримку молодочехів, соціал-демократів та інших прихильників виборчої реформи, які внесли на розгляд Палати Послів чотири екстренні пропозиції з цього приводу. Суть іiї полягала в тому, що діючі виборчі правила, навіть після реформи 1896 року, не відповідали умовам часу, а тому, йшлося у виступі Ю. Романчука, “наша Палата Послів не може вважатися за дійсний вираз загальної волі народу" [13]. Українські парламентарі пропонували цісарю відмовитися від політики цензів на виборах, надавши кожному народу Австро-Угорщини таке число мандатів, яке б відповідало територіальним розмірам краю та кількості його населення.

28 листопада 1905 р. прем'єр-міністр барон П. Гавч пообіцяв усім народам Австрії еру загального, безпосереднього і рівного виборчого права, що дозволило українцям створити Народний комітет у справі виборчої реформи, очільниками якого стали Ю. Романчук і К. Левицький.

Виступаючи 1 грудня 1905 р. під час обговорення проекту закону в Державній Раді, Ю. Романчук наголосив, що “від початку дев'яностих років тисячі петицій надійшли від українських громад, в яких вимагається забезпечення прямих виборів до парламенту" [14]. Він не погоджувався із намаганнями окремих депутатів зробити так, щоб виборчі округи були різними за кількістю населення і щоб в окремих коронних краях були різні “ключі для розподілу мандатів”. Не сприймав Ю.Романчук і пропозиції члена чеської парламентської фракції про те, що краї із більшим господарським значенням і вищою культурою повинні отримати в парламенті більше мандатів. Він відстоював необхідність створення окремих національних виборчих округів у Галичині, із визначеним числом мандатів для польської та української національностей, а також пропонував установити обов'язковість участі громадян у виборах, сподіваючись що виборча реформа доведе “народи до їхніх прав, до рівноправності” [13].

Але шлях до прийняття виборчої реформи був непростим. Куріальну систему уряд намагався відмінити через діючий парламент, який був “головним звеном теперішньої, пережитої вже конституції” [15]. Тому годі було сподіватись, щоби “засідаючі в нім, собі самим видали засуд смерті...” [15]. Це швидко підтвердилося: великі парламентські представництва і партії, зокрема, “польське сторонництво”, всіляко чинили опір конституційним змінам, попри те, що урядовий проект залишав їм привілейоване становище у Галичині. Навіть прихильники демократичного виборчого права - польські соціал-демократи на чолі 3 I. Дашинським і “людовці” на чолі з Я. Стапінсь- 
ким, які піддавали критиці польське представництво і його лідера графа Дзедушицького, не погоджувалися з пропозицією Ю. Романчука про поділ виборців за національністю та обов'язковість участі у виборах євреїв і визнання їх за окрему націю. Натомість представники меншості, в т. ч. українці, відстоювали ідею прямих виборів до парламенту.

За таких обставин прихильники виборчої реформи закликали уряд підготувати поправки до конституції без участі найвищого представницького органу держави. "Коли віденські круги справді хочуть провести виборчу реформу, писала газета “Діло”, то дорога до сего рішучо не веде через парламент. Одиноко розумним виходом остає позапарляментарне октройованє нової виборчої реформи. Тоді правительство не потребувало би оглядатися на жменю парламентарних інтриганів..., але, находячи санкцію свого кроку в волі міліонів, мало би вільну руку в переведеню реформи на основах справедливості" [16].

Ю. Романчук підтримував саме такий підхід до зміни Конституції і добивався розпуску парламенту, який, на його думку, був основним гальмом при запровадженні загального виборчого права громадян. Цю позицію очільник Руського клубу послідовно відстоював у Державній Раді. Водночас як голова Народного Комітету УНДП Ю. Романчук використовував і позапарламентські методи боротьби: ініціював народні віче, мітинги, входив до складу делегацій, які вимагали від цісаря запровадження загального виборчого права [17]. Він був твердо переконаний, що загальна політична мобілізація народу істотно прискорить досягнення омріяної мети. “Лише тоді, зазначалось в друкованому органі УНДП, коли по дальше буде доходити до Відня гомін масового ропоту рускіх віч і зборів - можна надіятись, що при виборчій реформі нас не покривдять" [16].

Незадовго уряд барона Гавча змушений був піти у відставку. Його наступник - князь Гогенльоге, хоч і скоригував проект Гавча, проте не встиг подати його на розгляд комісій з виборчої реформи. I лише кабінету Бека вдалося це зробити, правда, без врахування жодних поправок. Це викликало масові протести у представників національних меншин i, зокрема, в українців. Їх турбувала пропорційна система виборів, яка надавала переваги полякам: послом від польської частини населення краю визнавався той кандидат, за якого проголосувало 25 \% виборців, тоді, як для обрання українського кандидата - треба було набрати 50-75 \% від загального числа голосів. Тому пропорційна виборча система не могла бути “охороною меншости", але стала би, в разі іiі прийняття, “рабунком на правах більшости" [18].

Виступаючи 20 березня 1906 р. при обговоренні урядового проекту, Ю. Романчук наголосив на необхідності як реформи виборчої системи в цілому, так і введення загального, рівного, прямого виборчого права. На жаль, уряд створював лише видимість реформи й не поспішав усувати існуючі протиріччя, стверджуючи, що існуючий парламент цього не зможе зробити. У відповідь очільник українського представництва заявив, що “державна партія” під маскою державних інтересів узурпувалась для того, щоб відстоювати свої права" [3].

Як прихильник повномасштабної реформи виборчої системи Ю. Романчук вніс наступні пропозиції до проекту конституційного закону:

1) справедливий і для Австрії доцільний розподіл мандатів не за територіальними, а за національними виборчими округами (розподіл виборців на національні курії);

2) в остаточному розподілі мандатів визнання “індивідуальності людини як найціннішого капіталу”;

3) усунення нерівності Галичини супроти інших країв і в той же час відмова від “відкритого сприяння польському елементові” всередині краю;

4) поліпшення правил про виборчі комісії 3 метою усунення виборчих шахрайств; необхідність утворити верховний виборчий трибунал для розслідування зловживань;

5) відокремленість питання про виборчу реформу від збільшення крайової автономії, зокрема Галичини, бо на ділі б це було б “відданням українського народу на поталу його безсовісних противників” [14].

Переконуючи законодавців у тому, що 3,5 млн. українців - найвірніший, найтихіший, але водночас найбідніший і знедолений народ монархії, Ю. Романчук разом з тим наголошував, що він ще й позбавлений своїх представницьких прав і цим не переймалася ані влада, ані жодна з партій коаліції” [3]. Захищаючи громадянські права рідного народу, Ю. Романчук стверджував, що як українці, так і кожен інший народ повинен був мати в середньому по 46 депутатів у імперській Раді, а не шосту частину 3 цього. Такі реформи він вважав фіктивними, лише для вигляду і які не відповідали вимогам часу" [3]. На його думку, зміна виборчого законодавства мала сприяти розвитку державного управління, регенерації державних структур і разом 3 тим не повинна штучно утримувати при владі застарілу ідеологію, а запроваджувати нову” [3].

\section{5. Висновки}

Попри свою недосконалість проведена реформа все ж дала змогу брати участь у виборах основній масі населення, тому в наступній парламентській кампанії кількість українських виборців зросла на $50 \%$ і вони вперше за останнє півстоліття збільшили своє парламентське представництво до 32 депутатів.

18 червня 1907 р. Ю. Романчука було переобрано головою спільного Українського парламентського клубу національно-демократичних, радикальних i москвофільських послів з Галичини й українських послів з Буковини. Від імені національного представництва він вніс державно-правову декларацію (подібно до заяв чехів, хорватів та сербів) про утворення національно-територіальної автономії для українців, яка розглядалась як необхідний етап на шляху до їх політичної самостійності в Галичині. Це було свідченням того, що українці “придбали значення і впливу в загально-державній політиці” [19] і почали сміливіше й активніше публічно декларувати, що метою їх діяльності є самостійний політичний, економічний, соціальний, культурний розвиток українського народу. 
Реальне ж втілення української національної ідеї в життя відбулось лише після створення Західноукраїнської Народної Республіки. Як член Української Національної Ради Ю. Романчук брав участь у підготовці законопроектів, які допомагали уряду ЗУНР створювати вертикаль влади на місцях. Розробив він також конституційний проект “Основи державного устрою Галицької Республіки” (1918р.), в якому ідея української державності знайшли своє найповніше відображення.

\section{Література}

1. Романчук, Ю. Промова на Других загальних зборах Народної Ради 26 грудня 1890 р. [Текст] / Ю. Романчук // “Діло” - 1890. - 29 грудня.

2. Stenograficzne sprawozdania Sejmu krajowego Krolestwa Galicyi I Lodomeryi wraz z wielkiem Księstwem Krakowskiem z roku 1895/96 [Text] / od 28 grunia 1895 do 8 lutego 1896.

3. Republik Österreich. Parlamentsdirektion (Abt. Parl.Dok./Archiv) 508. Sitzsung der XI [Text] / Session am 6. Juni 1896. S. 25832.

4. Монолатій, I. "Viribus unitis". Інституціоналізація політичної системи Австро-Угорщини: вимушені ініціативи й напівдекларації [Текст] / I. Монолатій // Вісник Прикарпатського університету. Історія. - 2009. - Вип. 16. C. 218-219. Галичині в контексті Конституції України [Текст] / М. М. Мацькевич // Право України. -1998. - № 11. - С. 107.

6. Аркуша, О. Русофільство в Галичині в середині XIX-початку XX ст: генеза, етапи розвитку, світогляд [Текст] / О. Аркуша, М. Мудрий // Вісник Львів. ун-ту, серія історична. - 1999. - Вип. 34. - С. 75-76.

7. Романчук, Ю. Галицька біда перед віденським парламентом. Справозданє з дискусії над наглячим внесенєм пос. Романчука після стенографічних протоколов [Текст] / Ю. Романчук. - Накладом М. Струсевича, 1896. - 40 с.

8. Дискусія над негайним внесенням пос. Романчука [Текст] / “Діло”. - Конституція в Галичині, 1896. 13 квітня; 25, 26 вересня.

9. Сфремова, Н. В. Проблеми реформування законодавства про вибори в Австро-Угорській імперії на території Галичини та Буковини [Текст] / Н. В. Єфремова // Держава і право. - 2010. - Вип. 48. - С. 82-83, 87.

10. Монолатій, І. С. Детермінантні фактори політичної участі (західноукраїнська парадигма транзитного періоду) [Текст] / І. С. Монолатій // Вісник СевНТУ. 2009. - Вип. 100. - С. 58-59.

11. “Діло” [Текст] / 1901. - 30 травня (12 червня).

12. Романчук, Ю. Виступ на засіданні бюджетної комісії [Текст] / Ю. Романчук // “Діло”. - 1901. - 30 травня (12 червня).

13. Цюцюра, Т. Б. Боротьба українців у віденському парламенті за загальне виборче право і національну автономію [Текст] / Т. Б. Цюцюра // Український історик. 1917. - XVII, Вип. 1-4 (65-68). - С. 51-52.

14. Романчук, Ю. Моїм виборцям. Справозданє 3 моєї посольської діяльності в роках 1901-1907 [Текст] / Ю. Романчук. - Львів - 26 с.
5. Мацькевич, М. М. Розвиток національної ідеї в

15. “Діло” [Текст] / 1903. - 20 листопада 3( грудня).

16. “Діло” [Текст] / 1906. - 18 (31) січня.

17. “Діло” [Текст] / 1906. - 11(24) січня, 26 січня (8 лютого).

18. “Діло” [Текст] / 1906. - 14 лютого.

19. Дорошенко, Д. Історія України: 3 малюнками: Для школи й родини [Текст] / Д. Дорошенко. - Передм. та комент. В. А. Смолія і В. М. Рички. - Київ, 1993. - 204 с.

\section{References}

1. Romanchuk, Y. (1890). From the speech at the second general meeting of the People's Council: Dilo.

2. Stenograficzne sprawozdania Sejmu krajowego Krolestwa Galicyi I Lodomeryi wraz z wielkiem Księstwem Krakowskiem z roku $1895 / 96$ od 28 do grunia 18958 lutego $1896,69$.

3. Republik Österreich. Parlamentsdirektion (Abt. Parl.Dok. / Archiv) 508. Sitzsung der XI. Session am 6. Juni 1896. S. 25832.

4. Monolatiy, I. (2009). "Viribus unitis". The institutionalization of the political system of Austria-Hungary, forced initiative and halfdeclarations: Bulletin of Prykarpatskiy University. History, 16, 218-219.

5. Matskevych, M. (1998). The development of the national idea in Galicia in the context of the Constitution of Ukraine:Ukrainian right, 11, 107.

6. Arkusha, O., Mudryy, M. (1999). Russophilism in Galicia in the mid-nineteenth and early twentieth centuries: genesis, stages of development, outlook: Bulletin of Lviv National University. History, 34, 75-76.

7. Romanchuk, Y. (1896). Galician matter before Vienna Parliament. Spravozdanye of debate over nahlyachym amended ambassador Romanchuk after stenographic protocols. Lviv: Circulation of Strusevych. Moscow, 4.

8. Discussion of immediate implementation of ambassador Romanchuk (1896). Dilo. The Constitution in Galicia. Dilo, 13 April, 25, 26 September.

9. Efremova, N. (2010). Restructuring law on elections to the Austro-Hungarian Empire in Galicia and Bukovina State and Law, 48, 82-83, 87.

10. Monolatiy, I. (2009). The determinant factors of political participation (Western paradigm of transitional period): Bulletin SevNTU. Issue 100: Political Science. Sevastopol: Publishing house SevNTU, 58-59.

11. Dilo (1901). 30 May (June 12).

12. Adress of Ambassador Romanchuk at meetings of budgetary Commission (1901). Dilo, 30 May (June 12).

13. Tsutsura, T. (1917). Ukrainian fight in Vienna parliament for universal suffrage and national autonomy: Ukrainian historian, XVII, 1-4 (65-68), 51-52.

14. Romanchuk, Y. (1908), To my electorate. Spravozdanye from my embassy activity in the 1901-1907, 26.

15. Dilo (1903). 20 November 3 (December).

16. Dilo (1906). 18 (31) January.

17. Dilo (1906). 11 (24) January, 26 January (February 8).

18. Dilo (1906). 14 February

19. Doroshenko, D. (1993). History of Ukraine: with pictures: For schools and families: Kyiv, 204.

Рекомендовано до публікаиії професором Б. Й. Тищиком Дата надходження рукопису 25.12.2014

Мельник Андрій Ігорович, аспірант, кафедра історії держави, права та політико-правових учень, Львівський національний університет ім. Івана Франка, вул. Січових Стрільців, 14, м. Львів, Україна, 79000 E-mail: melnyk0982@gmail.com 